only books of 'relevance' to the North Atlantic market are still considered viable publishing propositions.

Obviously, the foreign exchange problems of many African governments lie at the heart of these problems. Equally obviously, the problem is hardly being dealt with under existing aid agency schemes, and is fairly low on any aid agency's list of priorities. It was agreed by all present that this was very shortsighted. Quite soon there will be a generation of students taught by lecturers unable to keep up with developments in their disciplines.

The symposium concluded that there were a number of solutions which might be sought:

fournals. It was agreed by all that journals are the best way of keeping absolutely up to date with recent research in various fields. Most African university libraries have been unable to subscribe to any journals for the past five years. Equally, it was agreed that most aid agencies do not like taking on board recurrent commitments. One possible way round this would be to apply for a large sum of money from an aid agency in order to set up a trust fund. The income from this fund could provide a wide number of journals for a large number of African universities. Each department within a university would be asked to submit the names of two journals to an organising committee and there would be a maximum number or total value of journals for each institution. Departments would be encouraged to nominate journals with a good book review section; in this way some knowledge of recent and relevant books in that field would be maintained.

Monographs. A number of suggestions were made as to ways in which the publication of important monographs could be assisted. Much more emphasis should be given to asking for subsidies with which to buy books. Also, mutually beneficial arrangements between publishers in the developed world and the developing world should be pursued. More attempts should be made to encourage indigenous publishing by means of licences and royalty arrangements.

Textbooks. Though not primarily concerned with textbooks, much of what was suggested under 'Monographs' could be applied even more forcefully to textbooks. Indigenous publishers could be encouraged more, aid agencies could widen the scope of their aid.

Tapes/other. Professor Roland Oliver outlined a scheme which he had already submitted to an aid agency, and which was supported by the symposium, for the exchange of cassette and hand-out materials between Africa and the developed world and between francophone and anglophone universities.

A number of other suggestions were made and can be found in the full report, which is available on request from the IAI. All participants agreed that it was important to act fast and to act effectively if African Studies research and scholarship within Africa and, ultimately, in the wider world, were not to be starved to death.

\title{
JOURNAL OF CULTURES AND IDEAS
}

We have received vol. 1, No. 1, of this new journal, published by the Alada Study Circle at the University of Ife, Nigeria, and due to appear twice a year. It invites the submission of articles dealing with the ideas and concepts of non-Western cultures. Articles dealing with the comparative analysis of Western and non- 
Western ideas and those of a transdisciplinary character are especially welcome. Book reviews and review articles are also to be published.

The first issue includes, among others, papers by Wande Abimbola on Ifa as a body of knowledge, by Rowland Abiodun on identity and the artistic process in Yoruba aesthetics, by Olufemi Morakinyo on the relevance of indigenous myths to mental health care in West Africa, by Ekong E. Ekong on concepts of metamorphosis in Ibibio society and by A. A. Akiwowo on interpretive sociology in the light of Yoruba religious concepts.

Articles should be sent to the Editor in Chief, Professor A. A. Akiwowo (Department of Sociology/Anthropology, University of Ife) and material for review to the Reviews Editor, Professor Oyin Ogunba (Department of Literature, University of Ife). All inquiries about subscriptions should be addressed to Professor Olufemi Morakinyo (Department of Psychiatry, University of Ife).

\section{COLLOQUIUM ON AFRICAN RELIGION AND RITUAL}

The Colloquium on African Religion and Ritual held its first Satterthwaite seminar, convened by Richard Werbner, from 23 to 26 April 1985 at Manchester University's Field Centre in the Lake District. Intended as a small research conference primarily for anthropologists from the United Kingdom, it brought eighteen anthropologists together, including some from the United States, Zimbabwe and Malawi, for sessions on the nature of symbolism, religious change and the state, the logic of ritual and other related themes. It is hoped that the seminar will take place annually. Richard Fardon of St Andrews University is the convenor for 1986 . 